\title{
The importance of local eosinophilia in the surgical outcome of chronic rhinosinusitis: a 3-year prospective observational study
}

\author{
Stephan Vlaminck*, Tom Vauterin, Bob Lerut
}

From 9th Symposium of Experimental Rhinology and Immunology of the Nose (SERIN 2013) Leuven, Belgium. 21-23 March 2013

\section{Background}

Patients with chronic rhinosinusitis with/without nasal polyps (CRSwNP/CRSsNP) benefit from endoscopic sinus surgery (ESS), with an estimated success rate of $80 \%$. At present, it remains unclear to what extent the presence of eosinophils, eosinophilic mucin (EM) and fungal hyphae $(\mathrm{FH})$ in secretions influence the clinical outcome and recurrence of disease after ESS.

\section{Objective}

By delineating CRS groups and subgroups based on the finding of eosinophils, EM and FH, differences in the frequency of recurrent disease after ESS over a longer period of time were investigated.

\section{Methods}

A prospective mono-centre study including 221 CRS patients who were unresponsive to medical treatment and underwent ESS, was performed. All tissue and sinonasal secretions were microscopically examined for the presence of eosinophils, EM and FH. Patients were followed for 3 years after surgery. Recurrence was defined according to the EPOS clinical control assessment, based on nasal endoscopy, symptoms and the need for systemic treatment.

\section{Results}

In total, 96 CRSwNP and 125 CRSsNP patients were included. Eosinophils were found in 78\% of CRSwNP patients compared to $42 \%$ in CRSsNP. Eosinophilic mucin was observed in $52 \%$ of the CRSwNP group versus $20 \%$ of the CRSsNP group. Furthermore, secretion analysis revealed $\mathrm{FH}$ in $11 \%$ CRSwNP patients compared to $3 \%$ CRSsNP patients. Recurrence in the total group was $22 \%$

AZ St John's Hospital, ENT/Rhinology, Bruges, Belgium over 3 years. CRSwNP patients with eosinophilic involvement showed a recurrence rate of $48 \%$. When the airway mucus secretions were positive for EM and FH the recurrence rate was even $73 \%$.

\section{Conclusion}

The presence of eosinophils greatly increases the risk of recurrent disease in CRSwNP patients. The finding of EM and $\mathrm{FH}$ in the collected sinonasal airway mucus secretions provides valuable information regarding the clinical outcome and the increased likelihood of CRS recurrence after ESS.

Published: 16 July 2013

doi:10.1186/2045-7022-3-S2-O12

Cite this article as: Vlaminck et al:: The importance of local eosinophilia in the surgical outcome of chronic rhinosinusitis: a 3-year prospective observational study. Clinical and Translational Allergy 2013 3(Suppl 2):012.

Submit your next manuscript to BioMed Central and take full advantage of:

- Convenient online submission

- Thorough peer review

- No space constraints or color figure charges

- Immediate publication on acceptance

- Inclusion in PubMed, CAS, Scopus and Google Scholar

- Research which is freely available for redistribution

\section{Biomed Central}

(c) 2013 Vlaminck et al; licensee BioMed Central Ltd. This is an Open Access article distributed under the terms of the Creative Commons Attribution License (http://creativecommons.org/licenses/by/2.0), which permits unrestricted use, distribution, and reproduction in any medium, provided the original work is properly cited. 